\title{
CLUSTERING AS ONE OF THE DIRECTIONS OF EFFECTIVE STRATEGIC MANAGEMENT IN THE MARITIME COMPLEX
}

\section{КЛАСТЕРИЗАЦІЯ ЯК ОДИН З НАПРЯМІВ ЕФЕКТИВНОГО СТРАТЕГІЧНОГО УПРАВЛІННЯ В МОРЕГОСПОДАРСЬКОМУ КОМПЛЕКСІ}

\section{UDC 334+65.012.32 \\ https://doi.org/10.32843/infrastruct38-17}

\section{Frasyniuk Tatyana}

Candidate of Economic Sciences,

Associate Professor

Senior Lecturer at the Department

of Economic Theory and Entrepreneurship

in Maritime Transport

National University

«Odessa Maritime Academy»

Babachenko Marina

Candidate of Economic Sciences,

Senior Lecturer at the Department

of Management and

Sea Transport Economics

National University

«Odessa Maritime Academy»

\begin{abstract}
The article analyzes the state and prospects of development of the national sea economic complex. Given the general trends of the global maritime trade market and the experience of the developed maritime countries, Ukraine should pay attention to the development and implementation of a clear state maritime policy, which aims to create adequate conditions for the formation of an effective strategy for the development of the sea economic complex. The importance of cluster policy for Ukraine and organizational and structural changes in accordance with the cluster strategy are analyzed. In view of this, it is justified the need to create special structures that will be responsible for the development of cluster projects. The main task is to create adequate regulated tools that will ensure their self-development and the formation of a favorable business climate for their transformation into an institutional system of cluster structure.

Key words: maritime complex, maritime administration, global market of transport services, cluster, strategic management, development strategy of the maritime complex.
\end{abstract}

В статье анализируется состояние и перспективы развития национального море хозяйственного комплекса. Учитывая общие тенденции развития глобального рынка морской торговли и опыт развитых морских держав Украине следует уделить внимание разработке и реализации четкой государственной морской политики, целью которой является создание адекватных условий для формирования эфрфективной стратегии развития море хозяйственного комплекса. Проанализировано значение кластерной политики для Украины и организационно-структурные изменения в соответствии кластерной стратегии. учитывая это обоснована необходимость создания специальных структур, которые будут отвечать за развитие кластерных проектов. Основная задача заключается в создании адекватного регулируемого инструментария, который обеспечит их саморазвитие и фрормирование благоприятного бизнес климата для их преобразования в институциональную систему кластерной структуры.

Ключевые слова: морехозяйственный комплекс, морское администрирование, глобальный рынок транспортных услуг, кластер, стратегическое управление, стратегия развития морехозяйственного комплекса.

У статті аналізується стан та перспективи розвитку національного море господарського комплексу. 3 огляду на загальні тенденції розвитку глобального ринку морської торгівлі та досвід розвинених морських держав Україні слід приділити увагу розробці та реалізації чіткої державної морської політики, метою якої є створення адекватних умов для фрормування ефекттивної стратегії розвитку море господарського комплексу. У статті розглянуті питання, пов'язані як з концептуальним обгрунтуванням, так і з практикою просторового розвитку морегосподарського комплексу України з огляду на формування глобального нового техніко-економічного укладу в судноплавстві і виходу діяльності морегосподарського комплексу на якісно інший рівень. Об'єктивні закономірності переходу до інноваційної траєкторії ефекту масштабу, впровадження в морегосподарський комплекс елементів постіндустріальної економіки, заснованої на знаннях, і ії національних інноваційних систем вимагають використання принципово нових підходів до стратегічного управління розвитку морегосподарського комплексу, перш за все в напрямку посилення його інтегрального характеру. Таким чином, розглядається комплексний підхід до системи стратегічного управління, що передбачає єдину, цілісну, скоординовану і послідовну національну морську політику, яка націлена на ефективний розвиток море господарського комплексу в цілому, збалансований розвиток його елементів, комплексне удосконалення та управління морською галуззю та адекватна система морського адміністрування на національному рівні. Увага акцентується на закономірностях збалансованості фрункціонування національного сектору морської транспортної індустрії. Виділяються аспекти кластеризаціі в інтересах підвищення конкурентоспроможності національного морегосподарського комплексу України. Визначено основну концепцію розвитку національного морегсподарського комплексу. Представлена схема структурних елементів концепції розвитку національного ринку морської торгівлі. Проаналізовано значення кластерної політики для України та організаційно-структурні зміни відповідно кластерній стратегії. З огляду на це обгрунтовано необхідність створення спеціальних структур, які будуть відповідати за розвиток кластерних проектів. Основне завдання полягає в створенні адекватного регульованого інструментарію, який забезпечить їх саморозвиток і фрормування сприятливого бізнес клімату для їх перетворення в інституційну систему кластерної структури.

Ключові слова: морегосподарський комплекс, морське адміністрування, глобальний ринок транспортних послуг, кластер, стратегічне управління, стратегія розвитку морегосподарського комплексу.

Problem Statement. An analysis of the status and development prospects of the national maritime economic complex, as well as the experience of the leading maritime powers, indicate the need for the development and implementation of a clear state maritime policy. The most important goal of this policy is to create adequate conditions for the formation of an effective strategy for the development of the maritime economic complex.

In view of this, in global conditions, the effective positioning of the national maritime economic complex of Ukraine is inferior to many developed coun- tries. The formation of a global new technical and economic structure in shipping has sharply actualized and brought to a qualitatively different level many issues related to both the conceptual justification and the practice of spatial development of the Ukrainian maritime sector. The objective laws of the transition to an innovative trajectory of the economies of scale, the introduction of knowledge-based elements of a post-industrial economy and its national innovation systems into the maritime economic complex require the use of fundamentally new approaches to the strategic management of the development of the mari- 
time economic complex, primarily in the direction of strengthening its integral character.

Moreover, the greatest effective development can be achieved through an integrated approach to the strategic management system. Such an approach involves the announcement of a unified, holistic, coordinated and consistent national maritime policy aimed at improving the effectiveness of all elements of the maritime economy, their balanced development, comprehensive improvement and management as a whole, as well as an adequate system of maritime administration at the national level. In addition, such a policy should facilitate the transition of the development of the national maritime trade market to a path of sustainable growth in the interests of future generations, which provides for the competitiveness of the national maritime industry with reliance on innovative development.

The theoretical significance of the study is determined by the need to develop scientific and methodological foundations for creating a network of clusters in the interest of increasing the competitiveness of the national maritime economic complex. To solve this problem, it seems logical to clarify the conceptual apparatus of the study of the world experience in implementing cluster policy, as well as national and foreign concepts of strategic forecasting and long-term planning in the development of Ukraine as a sea power.

Literature Review. The information base of the article was made up by official data of state statistical reporting, in particular, materials of the State Statistics Service of Ukraine, international organizations, publications and a database of IMO, Eurostat and other information banks, including statistical agencies from around the world, official Internet resources of government bodies, national and foreign analytical reports on the spatial development of maritime activities of Ukraine and other countries, scientific, methodological, regulatory and informational and educational publications of the Ukrainian and foreign authors related to the topics being studied.

The cluster concept was considered in the publications of such authors as E.A. Boyko, N.G. Grebenik, M.V. Botnaruk, S.V. Kryzhanovsky, who, in particular, substantiated the necessity of creating maritime clusters and, on this basis, determined the factors of increasing competitiveness of the maritime units.

It should be noted that the theoretical and methodological studies related to the subject of strategic management research in the effective development of all subsystems of the maritime economic complex are practically absent, due to the relative novelty of the proposed concepts.

Research Objective. The purpose of this article is to determine and scientifically and methodologically substantiate the development of clusters to increase the effectiveness of strategic management in the development of the national maritime economic complex of Ukraine.
Key Results. The results of functioning and the state of the national maritime economic complex show that more attention should be paid to the issues of strategic management in this industry. First of all, it is necessary to determine the concept of the development strategy of the national maritime economic complex.

The development strategy of the national maritime economic complex is the systematization and formulation of long-term economic development goals and the development of basic methods and ways to achieve them.

The socio-economic and resource goals of the formation and choice of strategy presuppose the existence of a complex set of indicators for making and monitoring the implementation of decisions. The systematization of the methods used at each stage of setting the goal, as well as the methods for calculating the expected parameters, make it possible to determine the fundamental directions for the development of the maritime economic complex.

The concept diagram of the development of the national maritime economic complex is presented in Figure 1. It includes the main indicators and objectives of the development of the national maritime economic complex.

At present, the reproductive core of the maritime economic complex, based on the latest technological base, is rapidly forming in the developed sea powers and developing states near the sea. A special place among the priority vectors of modernization is occupied by the problem of introducing modern forms of spatial organization of the economy, among which the cluster is a priority. Improving the competitiveness of the Ukrainian maritime trade market through the clustering of the maritime industry is fully in line with the national strategic approach to the country's socio-economic development. The concept of longterm socio-economic development of Ukraine should consider the creation of a network of territorial-production clusters that realize the competitive potential of the territories, the formation of a number of innovative high-tech clusters in the country.

The importance of clusters and cluster policy for Ukraine lies in their ability to impart a knowledgebased nature to traditional resource development of the sea, to promote diversification of the economy, to promote the dynamic development of transport, energy, communication infrastructure, the growth of small and medium-sized businesses, and the introduction of public-private partnership instruments in maritime activities, including creation of a network of sites for regular interaction of business, scientific and educational structures, civil society institutions the EU ETS and public authorities.

In accordance with the cluster strategy, the organization of management of the strategic development of the maritime complex involves certain organiza- 
Concept for the development of the national marine economic complex

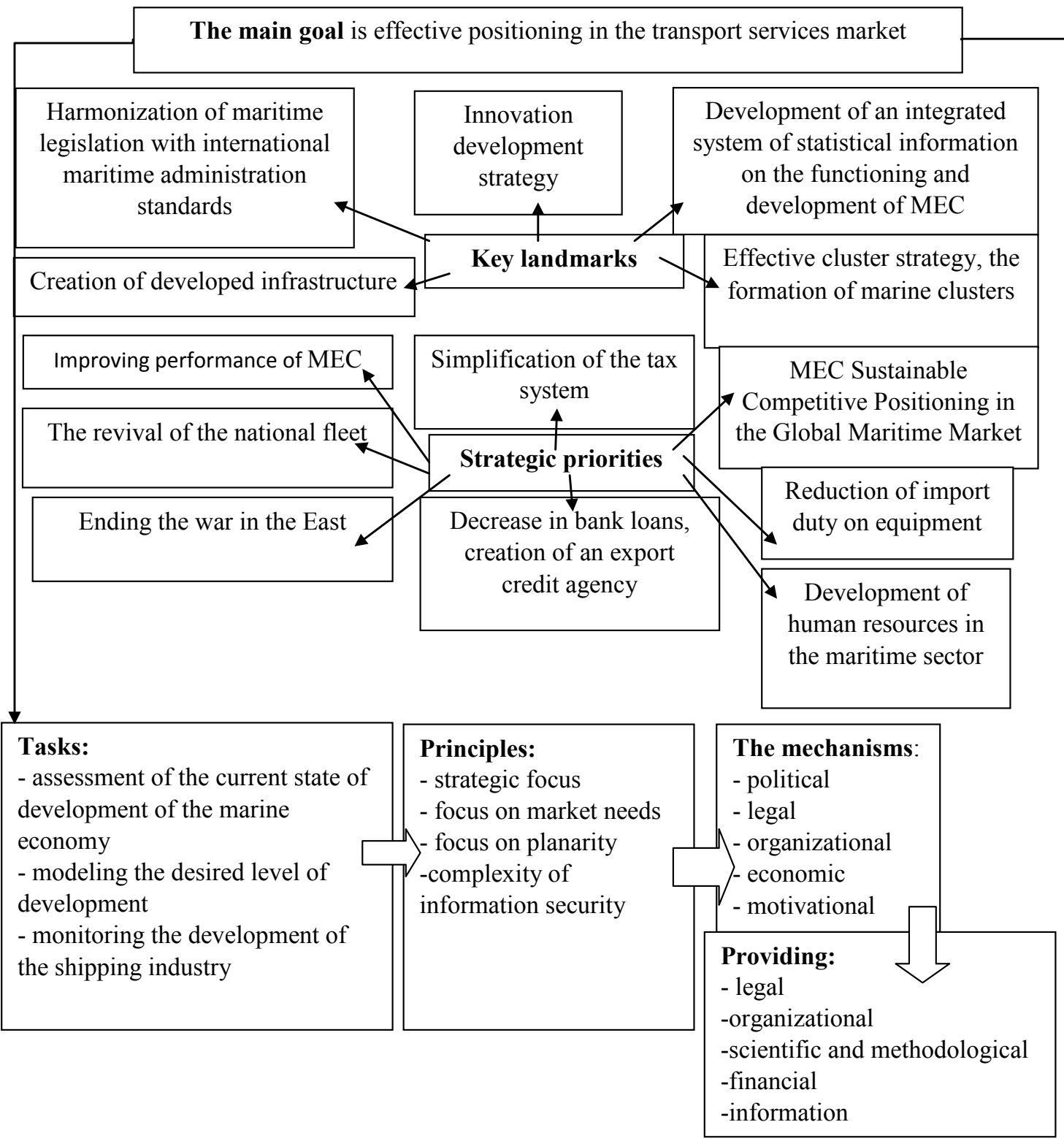

Expected results: improving the efficiency of the MEC, increasing freight and ship turnover, increasing the innovative activity of enterprises, raising the standard of living of the population, reducing unemployment, becoming Ukraine a sea power.

Fig. 1. Structural elements of the concept of development of the national maritime economic complex Source: developed by the authors

tional and structural changes in the administration system. In view of this, it is necessary to create special structures that will be responsible for the development of cluster projects. Basic institutional elements of the cluster, such as, for example, maritime administrations, already exist. However, the main task is to create adequate regulated tools that will ensure their self-development and the formation of a favorable business climate for their transformation into an institutional system of cluster structure.
Clustering allows the state to formulate a strategy in the field of integrated socio-economic development of the maritime complex region, taking into account its accumulated potential. Cluster policy is a kind of integral phenomenon, as it combines national and regional policies, policies for supporting small businesses, attracting foreign and domestic investments, innovative, scientific, technical, educational and other types of policies.

Thus, the cluster strategy for the development of the maritime economic complex consists in ensuring 
a stable unity of fundamental science, engineering sector of design and development, high-tech production sector, financial and organizational infrastructure and government regulatory institutions at various levels, within the framework of which there is a coordination mechanism for the technical re-equipment of the maritime cluster. Only within the framework of the given interconnection, favorable conditions are formed for making effective investment decisions aimed at developing the maritime industry and ensuring a stable positioning of the national maritime trade market in the global market system.

Conclusions. As world practice shows, one of the promising areas for the effective positioning of Ukraine in the international division of labor, increasing the competitiveness of the national economy is the effective implementation of cluster policy, the creation and development of a network of clusters of various specializations. It is this approach that creates the prerequisites for diversifying the economy, contributes to the strengthening of intersectoral, interregional and international relations, contributes to the industrialization and establishment of the service market, the intensification of public-private partnerships, which together leads to sustainable socio-economic growth and balanced national development of the country.

Clustering has become one of the main directions of state policy to increase national and regional competitiveness in developed maritime powers and actively developing countries by the sea. In contrast to traditional maritime policy, where a certain branch of the maritime economy complex is chosen as an object, the cluster approach combines intersectoral and territorial principles.

The cluster allows Ukraine to develop a comprehensive view of the state policy of national development of the country, taking into account the potential for socio-economic growth, promising national and global trends and changes in the structure of the main factors of production based on the synergistic relationship between the main actors of the maritime economic complex, shared vision and common goals.

\section{REFERENCES:}

1. Babachenko M.V. (2014) Parametry i faktory strukturnikh transformatsiy torgovogo flota mira [Parameters and factors of structural transformations of the merchant fleet of the world]. Visnyk Khmelnytskoho natsionalnoho universytetu. Naukovyi zhurnal. Ekonomichni nauky [Bulletin of Khmelnitsky National University. Scientific journal. Economic sciences], vol. 3, no. 2, pp. 200-203.
2. Bareev T. (2012) Ponjatie I osnovnye cherty klastera [The concept and main features of the cluster]. Jekonomicheskie nauki [Economicscience], No 8, p. 106.

3. Kostenko O. (2016) Sostav i struktura strategii razvitija klastera: piramida strategij [The composition and structure of the cluster development strategy: a pyramid of strategies]. Jekonomika I predprinimatel'stvo [Economics and Entrepreneurship], no. 9(74), p. 641.

4. Kurkudinov E. (2010) Klasternyj podhod kak tehnologija upravlenija jekonomicheskim razvitiem regiona [Cluster approach as a technology for managing the economic development of a region]. Jekonomicheskie nauki [Economic science], No. 10(71), pp. 171-172.

5. Frasinyuk T.I. (2012) Faktory i zadachi morskogo administrirovaniya $v$ razvitii ukrainskogo torgovogo flota [Factors and tasks of maritime administration in the development of the Ukrainian merchant fleet]. Visnyk ekonomiky transportu i promyslovosti [Bulletin of Economics of Transport and Industry]. Issue. 39. Pp. 76-79.

6. Sham'enova G., Najdenov M. (2016) Teoreticheskie aspekty formirovanija innovacionnyh strategij klasternogo razvitija regionov [Theoretical aspects of the formation of innovative strategies for cluster development of regions]. Innovacionnaja dejatel'nost' [Innovation activity], No. 1(36), pp. 68-69.

7. Frasyniuk T., Primacheva N. (2018) Maritime Shipping Industry Within the System of Global Economic Relations Sustainability. International Journal of Engineering \& Technology. Vol.7, No 4.3 : Special Issue 3. Pp. 451-455.

\section{БІБЛІОГРАФІЧНИЙ СПИСОК:}

1. Бабаченко М.В. Параметры и фракторы структурних транссормаций торгового фрлота мира. Вісник Хмельницького національного університету. Науковий журнал. Економічні науки. 2014. № 2, т. 3. C. 200-203.

2. Бареев Т. Понятие и основные черты кластера. Экономические науки. 2012. № 8. С.106.

3. Костенко О. Состав и структура стратегии развития кластера: пирамида стратегий. Экономика и предпринимательство. 2016. № 9(74). С. 641.

4. Куркудинов Е. Кластерный подход как технология управления экономическим развитием региона. Экономические науки. 2010. № 10(71). С. 171-172.

5. Фрасинюк Т.И. Факторы и задачи морского администрирования в развитии украинского торгового фрлота. Вісник економіки транспорту і промисловості. 2012. Вип. 39. С. 76-79.

6. Шамьенова Г., Найденов М. Теоретические аспекты формирования инновационных стратегий кластерного развития регионов. Инновационная деятельность. 2016. № 1(36). С. 68-69.

7. Frasyniuk T., Primacheva N. Maritime Shipping Industry Within the System of Global Economic Relations Sustainability. International Journal of Engineering \& Technology. 2018. Vol. 7, No 4.3: Special Issue 3. Pp. 451-455. 
Frasyniuk Tatyana

Candidate of Economic Sciences, Associate Professor, Senior Lecturer at the Department of Economic Theory and Entrepreneurship in Maritime Transport National University «Odessa Maritime Academy»

Babachenko Marina

Candidate of Economic Sciences, Senior Lecturer at the Department of Management and Sea Transport Economics National University «Odessa Maritime Academy»

\section{CLUSTERING AS ONE OF THE DIRECTIONS OF EFFECTIVE STRATEGIC MANAGEMENT IN THE MARITIME COMPLEX}

A comprehensive approach to the strategic management system is being considered, providing for a single, integrated, coordinated and consistent national maritime policy aimed at efficient development of the sea of the economic complex as a whole, balanced development of its elements, comprehensive improvement and management of the maritime industry and an adequate system of maritime administration levels. The focus is on the patterns of balance in the functioning of the national sector of the maritime transport industry. The aspects of clustering are highlighted in the interests of increasing the competitiveness of the national maritime economic complex of Ukraine.

The basic concept of development of the national maritime economic complex is defined. The scheme of structural elements of the concept of development of the national maritime trade market is presented.

Clustering has become one of the main directions of state policy to increase national and regional competitiveness in developed maritime powers and actively developing countries by the sea. In contrast to traditional maritime policy, where a certain branch of the maritime economy complex is chosen as an object, the cluster approach combines intersectoral and territorial principles.

The importance of cluster policy for Ukraine and organizational and structural changes in accordance with the cluster strategy are analyzed. In view of this, it is justified the need to create special structures that will be responsible for the development of cluster projects. The main task is to create adequate regulated tools that will ensure their self-development and the formation of a favorable business climate for their transformation into an institutional system of cluster structure. The cluster allows Ukraine to develop a comprehensive view of the state policy of national development of the country, taking into account the potential for socio-economic growth, to take into account promising national and global trends and changes in the structure of the main factors of production based on the synergistic relationship between the main actors of the maritime economic complex, shared vision and common goals.

The greatest effective development can be achieved through an integrated approach to the strategic management system. Such an approach involves the announcement of a unified, holistic, coordinated and consistent national maritime policy aimed at improving the effectiveness of all elements of the maritime economy, their balanced development, comprehensive improvement and management as a whole, as well as an adequate system of maritime administration at the national level. In addition, such a policy should facilitate the transition of the development of the national maritime trade market to a path of sustainable growth in the interests of future generations, which provides for the competitiveness of the national maritime industry with reliance on innovative development. The theoretical significance of the study is determined by the need to develop scientific and methodological foundations for creating a network of clusters in the interest of increasing the competitiveness of the national maritime economic complex. To solve this problem, it seems logical to clarify the conceptual apparatus of the study of the world experience in implementing cluster policy, as well as national and foreign concepts of strategic forecasting and long-term planning in the development of Ukraine as a sea power. 